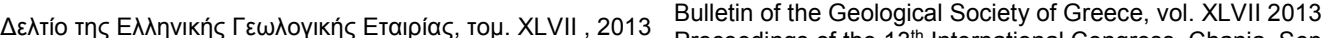
Proceedings of the $13^{\text {th }}$ International Congress, Chania, Sept.

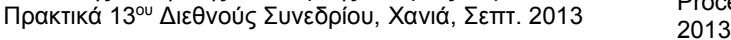

\title{
REMOVAL OF MALACHITE GREEN DYE FROM AQUEOUS SOLUTIONS BY DIASPORIC GREEK RAW BAUXITE
}

\author{
Georgiadis I.K. ${ }^{1}$, Papadopoulos A. ${ }^{1}$, Filippidis A. ${ }^{1}$, Godelitsas A. ${ }^{2}$, \\ Tsirambides A. ${ }^{1}$ and Vogiatzis D. ${ }^{1}$
}

${ }^{1}$ Aristotle University of Thessaloniki, School of Geology, Department of Mineralogy-PetrologyEconomicGeology, igeorgia@chem.auth.gr,argpapad@geo.auth.gr,anestis@geo.auth.gr, ananias@geo.auth.gr,dvogias@geo.auth.gr

${ }^{2}$ National and Kapodistrian University of Athens, Faculty of Geology and Geoenvironment, Department of Mineralogy and Petrology,agodel@geol.uoa.gr

\begin{abstract}
Raw bauxite from Klisoura mine (Prefecture of Fokida, Greece) containing $72 \mathrm{wt} \%$ diaspore, $16 \mathrm{wt} . \%$ hematite, $6 \mathrm{wt} . \%$ quartz, $4 \mathrm{wt} \%$ anatase and $2 \mathrm{wt} . \%$ calcite, has been used for the removal of malachite green dye from aqueous solutions. The batch type experiments were conducted with $10 \mathrm{ml}$ of solution, at $\mathrm{pH}=\mathrm{pH}_{Z P C}=6.7$ and contact time $1 \mathrm{~h}$. The initial concentration of malachite green dye was $10 \mathrm{mg} / \mathrm{l}$, the bauxite quantity was $0.02 \mathrm{~g}, 0.04 \mathrm{~g}, 0.06 \mathrm{~g}, 0.1 \mathrm{~g}$ and $0.2 \mathrm{~g}$. The highest adsorption capacity achieved was $4.5 \mathrm{mg} / \mathrm{g}$ (90\% removal) using $0.02 \mathrm{~g}$ bauxite. The removal capacity of raw bauxite is comparable to other non-conventional adsorbents, such as neem sawdust, sugar cane dust and cane root carbon.
\end{abstract}

Key words: Wastewater treatment, textile wastewater, adsorption, industrial minerals and rocks.

\section{Пєрí $\eta \Psi \eta$}

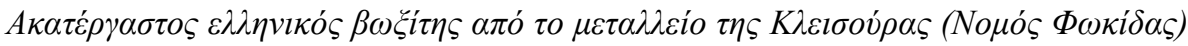

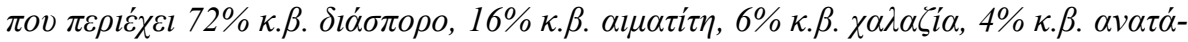

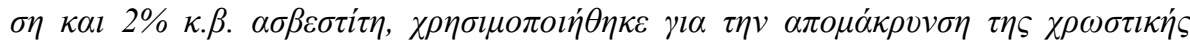

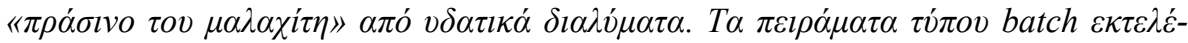

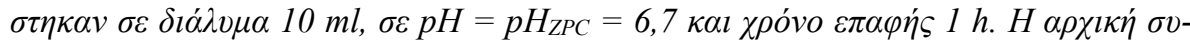

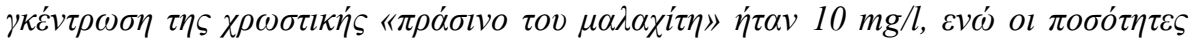

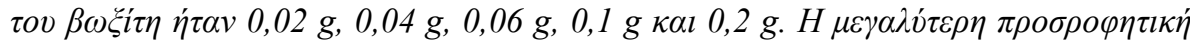

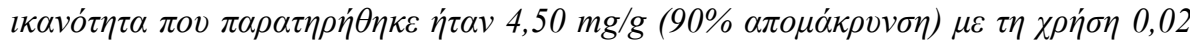

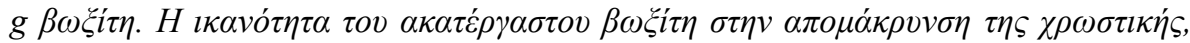

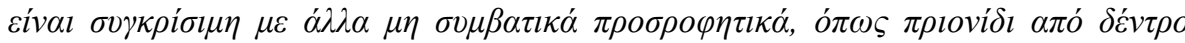

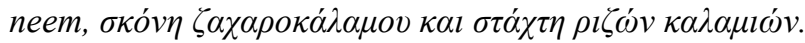

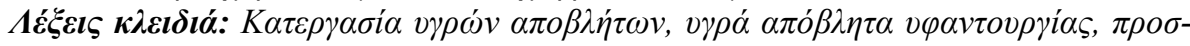

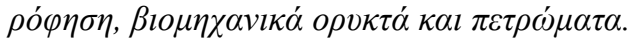

\section{Introduction}

Removal of pollutants from wastewater is of crucial importance in environmental protection. The removal of non-biodegradable pollutants is of great interest due to their heavy potential environ-

$\underline{\text { XLVII. No } 2-927}$ 
mental impact. Several types of industrial dyes are commonly considered as non-biodegradable pollutants. Malachite green (a N-methylated diaminotriphenyl methane) dye is a commonly used non-biodegradable industrial dye.

Malachite green dye may have serious impact on human health and the environment in general. It has been reported to cause carcinogenesis, mutagenesis, chromosomal fractures, teratogenecity and respiratory toxicity. Histopathological effects of malachite green dye include multi-organ tissue injury (Srivastava et al., 2004). Despite all these facts, malachite green dye is still in use in aquaculture and other industries, and no effective alternative to it has yet been found.

Adsorption on activated carbon has been proven to be effective in removing dyes from aqueous solutions. However, activated carbon is still considered expensive and currently the research is focused on the development of low-cost adsorbents for this purpose. Low-cost adsorbents include natural, agricultural and industrial by-product wastes. They are attractive because of their abundant availability at low or no cost and their good performance in removing dyes from aqueous solutions.

Numerous adsorbents for malachite green dye have been used. Activated carbon from pine sawdust (Akmil-Basar et al., 2005), commercially available powdered activated carbon (Kumar and Sivanesan, 2006), activated carbon from lignite (Onal et al., 2007), carbon based adsorbent from the pyrolysis of waste materials from paper industry and pine bark (Mendez et al., 2007) and bentonite (Bulut et al., 2008). A number of non-conventional sorbents (Crini, 2006) such as sugarcane dust, algae, sawdust, bottom ash, fly ash, de-oiled soya, maize cob, peat, iron humate, mixed sorbents, microbial biomass, activated slag, waste product from agriculture, magnetic nanoparticle and coal have been tested for malachite green dye adsorption: Sugar cane dust (Khattri and Singh, 1999), neem sawdust (Khattri and Singh, 2000), chemically modified rice straw (Gong et al., 2006), hen feathers (Mittal, 2006), cyclodextrin based adsorbent, (Crini et al., 2007) rubber wood (Kumar and Sivanesan, 2007), lemon peel (Kumar, 2007) and Arundo donax root carbon (Zhang et al., 2008) were also used. An extensive review on nonconventional low-cost adsorbents for dye removal was reported by Das et al. (2009). For the same purpose, surfactant modified alumina has also been used (Das et al., 2009). High quality natural zeolite have been used for the purification of dye-work wastewaters (Filippidis, 2008, 2010, 2013; Filippidis et al., 2008).

Bauxite ore may exhibit a variety of colors and is mainly composed of amorphous and/or crystalline alumina oxides and hydroxides, namely gibbsite, boemite and diaspore. It is mainly used for the production of aluminum metal. Additionally, bauxite is used for numerous nonmetallurgical end uses. Through the Bayer process, bauxite is converted to alumina $\left(\mathrm{Al}_{2} \mathrm{O}_{3}\right)$; especially activated alumina is used as adsorbent, desiccant and catalyst, while calcined alumina is used in abrasives, ceramics and refractories. Hard-burned (sintered) calcined alumina is used for the production of tabular alumina and principally for high performance refractory materials. Finally, fused alumina is mainly used for abrasives and refractories (e.g., Harben and Dickson, 1983; Benbow, 1988; Bolger, 1997; Crossley, 2001; Harben, 2002; Taylor, 2003).

The present study investigates, for the first time, the ability of diasporic raw bauxite (a low-cost adsorbent) to remove the malachite green dye from aqueous solutions.

\section{Materials and Methods}

The bauxite sample used in this study was obtained from b3 bauxitic horizon of the Klisoura open pit mine, Prefecture of Fokida, Central Greece. In the Parnassus-Ghiona geotectonic zone or Parnassus zone, three bauxitic horizons were formed, b1) Middle/Upper Jurassic, b2) Kimmeridgian/Tithonian and b3) Upper Aptian, Lower Albian, Lower Senonian (e.g., Kiskyras, 1982; Tataris, 1986).

Polished and polished thin sections of the bauxite have been studied. The mineralogical composition of the samples was determined by X-Ray Powder Diffraction (XRPD) analysis, using a 
Philips diffractometer with Ni-filtered $\mathrm{CuK} \alpha$ radiation on randomly oriented samples. The sample was scanned from $3^{\circ}$ to $43^{\circ} 2 \theta$ at a scanning speed of $1.2^{\circ} / \mathrm{min}$. Semi-quantitative estimates of the abundance of the mineral phases were derived from the PXRD data, using the intensity (cps) of specific reflections, the density and the mass absorption coefficients for $\mathrm{CuK}_{\alpha}$ radiation of the minerals present.

The chemical composition of the sample was measured by a Perkin Elmer 3300 Atomic Absorption Spectrometer with a graphite furnace following standard wet chemical methods. The loss of ignition (LOI) of the bauxite sample was determined gravimetrically by firing $0.8 \mathrm{~g}$ of the powder at $925^{\circ} \mathrm{C}$ for $45 \mathrm{~min}$.

The raw bauxite sample was crushed by the use of agate mortar to a particle size $<63 \mu \mathrm{m}$. Prior to the adsorption experiments the pulverized raw bauxite was dried by heating $\left(75^{\circ} \mathrm{C}\right.$ for $\left.24 \mathrm{~h}\right)$. The $\mathrm{pH}$ at the potential of zero charge of the adsorbent $\left(\mathrm{pH}_{\mathrm{ZPC}}\right)$ was determined using the $\mathrm{pH}$ drift method (Jia et al., 2002; Govindasamy et al., 2009): A solution of $0.01 \mathrm{M} \mathrm{NaCl}$ was prepared and eleven aliquots of $50 \mathrm{ml}$ each were taken; their $\mathrm{pH}$ was fixed between 2 and 12 using $1 \mathrm{M} \mathrm{HCl}$ and $1 \mathrm{M} \mathrm{NaOH}$ solutions. In every aliquot $0.1 \mathrm{~g}$ of adsorbent was added and the final $\mathrm{pH}$ of the suspension was measured (Hanna pH $301 \mathrm{pH} /$ ion meter) after $24 \mathrm{~h}$.

Malachite green dye (malachitgrün-oxalat pro analysi, C.I. 42,000, FW=927.10 g/mol, Merck) was used as adsorbate, without further purification. Stock solution was prepared by diluting exactly $400 \mathrm{mg}$ of malachite green dye in one litre of deionized water. The working solutions were prepared by the appropriate dilution of this solution. The adsorption of malachite green dye on natural bauxite was investigated in batch mode experiments using the standard immersion method (Rouquerol et al., 1999). For this reason, working solutions of initial concentration $10 \mathrm{mg} / \mathrm{l}$ in malachite green dye were prepared. Their $\mathrm{pH}$ was fixed to the desired value by using $1 \mathrm{M} \mathrm{HCl}$ and $1 \mathrm{M} \mathrm{NaOH}$ solutions. Sealing test tubes were used containing aliquots of $10 \mathrm{ml}$ of solution with $0.02 \mathrm{~g}, 0.04 \mathrm{~g}, 0.06 \mathrm{~g}, 0.1 \mathrm{~g}$ and $0.2 \mathrm{~g}$ of powdered raw bauxite. They were shaken for $1 \mathrm{~h}$ in 20 $\mathrm{rpm}$ and then centrifuged in $3000 \mathrm{rpm}$ for $15 \mathrm{~min}$. The concentration of the remaining malachite green dye in the supernatant solution was then measured using SHIMADZU UV-1700 PharmaSpec spectrophotometer at $\lambda=619 \mathrm{~nm}$ (measured value). All the adsorption studies were carried out at ambient temperature.

\section{Results and Discussion}

The texture of the studied bauxite sample is oolitic (Figure 1). The oolits are usually smaller than 2 $\mathrm{mm}$, their shape is round or elliptic and are usually consisted of Al-minerals (diaspore) and Feminerals (hematite). More specifically, the oolite consists of either a mineral or mainly of concentric shells of alternating mineral composition, which indicate varying deposition conditions. Usually, either the diasporic oolits are surrounded by an outer hematite shell or hematite can be found as distinguished spots into the main mass. Finally, hematite can be found as a filling material at the rock cracks.

The XRPD analysis revealed that the bauxite sample contains $72 \mathrm{wt} . \%$ diaspore (theoretical chemical forlula $\mathrm{AlOOH}), 16$ wt.\% hematite $\left(\mathrm{Fe}_{2} \mathrm{O}_{3}\right), 6$ wt. $\%$ quartz $\left(\mathrm{SiO}_{2}\right), 4$ wt. $\%$ anatase $\left(\mathrm{TiO}_{2}\right)$ and 2 wt.\% calcite $\left(\mathrm{CaCO}_{3}\right)$. The mineralogical composition of the raw bauxite is in good agreement (Table 1).

The determination of $\mathrm{pH}_{\mathrm{ZPC}}$ (i.e. the $\mathrm{pH}$ at which the mineral's surface charge becomes zero) is of great importance for bauxite, as its major mineral constituent (diaspore) encompass hydroxyl ions into their strucrure; the latter are very reactive, contributing to the total mineral electric charge. At $\mathrm{pH}<\mathrm{pH}_{\mathrm{ZPC}}$ raw bauxite exhibits a net positive charge, whereas at $\mathrm{pH}>\mathrm{pH}_{\mathrm{ZPC}}$ a net negative charge (Krauskopf and Bird, 1995). The studied sample demonstrates $\mathrm{pH}_{\mathrm{ZPC}}=6.7$. In comparison, hematite has $\mathrm{pH}_{\mathrm{ZPC}}$ between 5 and 9 , goethite has $\mathrm{pH}_{\mathrm{ZPC}}$ ranging around 7.5 and gibbsite has $\mathrm{pH}_{\mathrm{ZPC}}$

XLVII. No 2 - 929 


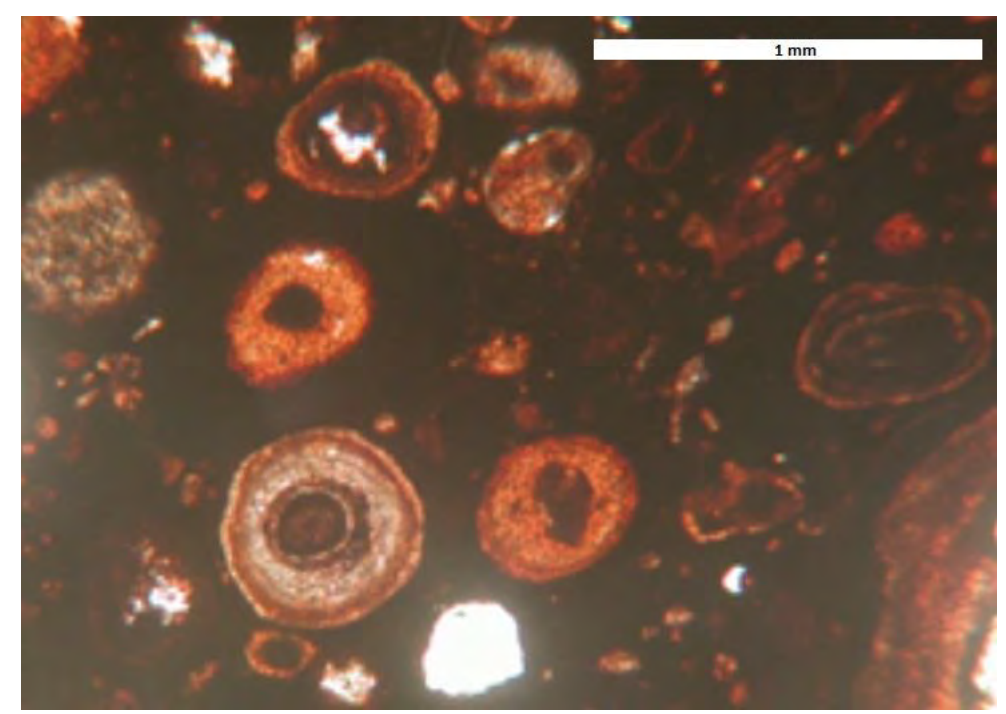

Figure 1 - Oolitic texture of the bauxite used (photomicrograph, polarizing microscope, $+\mathrm{N}$ ).

Table 1 - Semi-quantitative mineralogical and chemical composition of the bauxite used.

\begin{tabular}{|lc|lc|lc|}
\hline \multicolumn{2}{|c|}{ Mineralogical composition (wt.\%) } & \multicolumn{4}{c|}{ Chemical composition (wt.\%) } \\
\hline Diaspore & 72 & $\mathrm{SiO}_{2}$ & 6.42 & $\mathrm{Na}_{2} \mathrm{O}$ & 0.12 \\
\hline Hematite & 16 & $\mathrm{Al}_{2} \mathrm{O}_{3}$ & 59.54 & $\mathrm{TiO}_{2}$ & 3.84 \\
\hline Quartz & 6 & $\mathrm{Fe}_{2} \mathrm{O}_{3}$ & 15.16 & $\mathrm{MnO}$ & 0.01 \\
\hline Anatase & 4 & $\mathrm{CaO}$ & 0.64 & $\mathrm{P}_{2} \mathrm{O}_{5}$ & 0.15 \\
\hline Calcite & 2 & $\mathrm{MgO}$ & 0.08 & LOI (loss on ignition) & 13.51 \\
\hline Total & 100 & $\mathrm{~K}_{2} \mathrm{O}$ & 0.02 & Total & 99.49 \\
\hline
\end{tabular}

$=9\left(\right.$ Krauskopf and Bird, 1995). For alumina a value of $\mathrm{pH}_{\mathrm{ZPC}}=9.15$ and poor adsorption capacity for malachite green dye at $\mathrm{pH}<\mathrm{pH}_{\mathrm{ZPC}}$ has been reported (Das et al., 2009). In general, the suspension of oxides in an aqueous solution must form distinct surface charge sites due to the following mechanism (Prado et al., 2008; Preocanin and Kallay, 2006):

$$
\begin{aligned}
\mathrm{MOH}_{2}^{+} & \leftrightarrow \mathrm{MOH}+\mathrm{H}^{+} \\
\mathrm{MOH} & \leftrightarrow \mathrm{MO}^{-}+\mathrm{H}^{+}
\end{aligned}
$$

and especially when hydroxyl ions are attached to aluminium cations, the following mechanism is proposed (Krauskopf and Bird, 1995):

$$
\begin{gathered}
\mathrm{Al}-\mathrm{OH}{ }^{+} \mathrm{H}^{+} \rightarrow \mathrm{Al}-\mathrm{OH}_{2}^{+} \\
\mathrm{Al}-\mathrm{OH}+\mathrm{OH}^{-} \rightarrow \mathrm{Al}-\mathrm{O}^{-}+\mathrm{H}_{2} \mathrm{O}
\end{gathered}
$$

The former reaction is favoured in acid solutions and the latter in basic solutions.

The effect of adsorbent dosage for malachite green dye removal at initial concentration $10 \mathrm{mg} / \mathrm{l}$ and solution $\mathrm{pH}=\mathrm{pH}_{\mathrm{ZPC}}=6.7$ is presented in Table 2 and demonstrated in Figure 3. The optimum solid to solution ratio was $0.1 \mathrm{~g}$ of bauxite powder to $10 \mathrm{ml}$ of solution. 
Table 2 - Adsorption of malachite green (MG) dye by bauxite (In all experiments: Solution volume $=10 \mathrm{ml}, \mathrm{pH}=6.7$ and contact time $=1 \mathrm{~h}$ ).

\begin{tabular}{|c|c|c|c|}
\hline $\begin{array}{c}\text { Initial concentration } \\
\text { of MG (mg/l) }\end{array}$ & $\begin{array}{c}\text { Amount of } \\
\text { bauxite added (g) }\end{array}$ & $\begin{array}{c}\text { Concentration of MG } \\
\text { after } \mathbf{1} \mathbf{~ h} \text { (mg/l) }\end{array}$ & $\begin{array}{c}\text { Adsorption } \\
\text { of MG (\%) }\end{array}$ \\
\hline 10 & 0.2 & 0.36 & 96.4 \\
\hline 10 & 0.1 & 0.13 & 98.7 \\
\hline 10 & 0.06 & 0.15 & 98.5 \\
\hline 10 & 0.04 & 0.29 & 97.1 \\
\hline 10 & 0.02 & 1.00 & 90.0 \\
\hline
\end{tabular}

The maximum adsorption capacity is approximately $99 \%$ with $0.1 \mathrm{~g}$ and $0.06 \mathrm{~g}$ of bauxite per 10 $\mathrm{ml}$ of malachite green dye solution. This value is comparable to other non-conventional adsorbents, such as neem sawdust, sugar cane dust, hen feathers and arundo donax root carbon (Khattri and Singh, 1999, 2000; Mittal, 2006; Zhang et al., 2008).

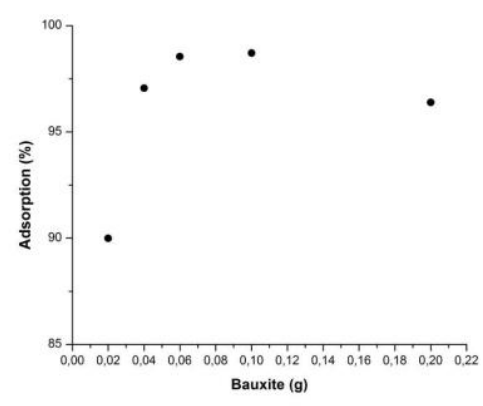

Figure 3 - Adsorption (\%) of malachite green dye onto raw bauxite.

This non linear solid to solution dependence is already well documented (Limousin et al., 2007). The reasons for this effect may include, the aggregation of the suspended particles (Voice et al., 1983; Di Toro et al., 1986), the occupied volume of the suspended particles (Celorie et al., 1989), the solute transfer rate onto the surface of the adsorbent (Nandi et al., 2008) and the potential splitting of the amount of dye compounds adsorbed onto the unit weight of the adsorbent (Govindasamy et al., 2009). The optimum experimental value for solid to solution ratio for geomedia, would be a value representative of the natural conditions. The latter though demonstrate such value in general too high to be used in batch experiments (e.g. in solids the ratio tends to unity) (Limousin et al., 2007). For malachite green dye concentrations of $20 \mathrm{mg} / 1 \leq \mathrm{C}_{\mathrm{o}} \leq 100 \mathrm{mg} / \mathrm{l}$, solid to solution ratio equal to $1: 100 \mathrm{~g} / \mathrm{ml}$, solution $\mathrm{pH}=5.3 \pm 0.2$, surfactant-modified alumina as adsorbent and at ambient temperature, the optimum time for malachite green removal was $30 \mathrm{~min}$ (Das et al., 2009).

In general, the decreasing order of adsorption capacities for various types of cationic dyes onto activated alumina (as amount of dye adsorbed per one gram of sorbent) is: Crystal violet $>$ malachite green $>$ rhodamine B $>$ methylene blue (Singh et al., 1975). Malachite green values of $4.615 \cdot 10^{-5} \mathrm{~g} / \mathrm{g}$ (with $\mathrm{k}=0.1248 \mathrm{~min}^{-1}$ ) and $7.590 \cdot 10^{-5} \mathrm{~g} / \mathrm{g}$ (with $\mathrm{k}=0.1139 \mathrm{~min}^{-1}$ ) were also reported and the first order rate law for the adsorption process was found to be followed (Singh et al., 1975). The adsorption of malachite green onto surfactant-modified alumina fits into the Langmuir model isotherm, with $\mathrm{q}_{\max }=185 \mathrm{mg} / \mathrm{g}$ (Das et al., 2009). In this study, the maximum adsorption capacity recorded $\left(\mathrm{q}_{\max }\right)$ was $4.5 \mathrm{mg} / \mathrm{g}$ for initial adsorbent quantity of $0.02 \mathrm{~g}$. 


\section{Conclusions}

The Greek raw bauxite as adsorbent is composed mainly of diaspore, with lesser hematite, quartz, anatase and calcite.

The adsorption capacity of diasporic raw bauxite increases up to approximately $99 \%$ for contact time $1 \mathrm{~h}$, initial malachite green dye concentration $10 \mathrm{mg} / \mathrm{l}$, solution $\mathrm{pH}=\mathrm{pH}_{\mathrm{ZPC}}=6.7$ and solution volume $10 \mathrm{ml}$. More specifically, for adsorbent dosage up to $0.06 \mathrm{~g}$ per $10 \mathrm{ml}$ of solution, the adsorption capacity increases rapidly to $99 \%$, then stabilizes to that value as the adsorbent amount increases up to $0.1 \mathrm{~g}$ and then slightly diminishes as more adsorbent is added.

The data presented, in conjunction were other literature, suggest that the phenomenon is more suitably described as a physical sorption process.

\section{References}

Akmil-Basar C., Onal Y., Kilicer T. and Eren D. 2005. Adsorption of high concentration malachite green by two activated carbons having different porous structures, J. Hazard. Mater. B, $127,73-80$.

Benbow J. 1988. Bauxite: Aluminating non-metallurgical sectors, Industrial Minerals, 252, 67-83.

Bolger R. 1997. Non - refractory bauxite, Variety but not much spice, Industrial Minerals, March 1997, 21-29.

Bulut E. Ozacaar M. and Ayhan Sengil I. 2008. Adsorption of malachite green onto bentonite: equilibrium and kinetic studies and process design, Micropor. Mesopor. Mat., 115/3, 234 246.

Celorie J.A., Woods S.L., Vinston T.S. and Istok J.D. 1989. A comparison of sorption equilibrium distribution coefficients using batch and centrifugation methods, J. Environ. Qual., 18, 307-313.

Crini G. 2006. Non-conventional low-cost adsorbents for dye removal: A review. Bioresour. Technol., 97, 1061-1085.

Crini G., Peindy H.N., Gimbert F. and Robert C. 2007. Removal of C. I. basic green 4 (malachite green) from aqueous solutions by adsorption using cyclodextrin-based adsorbent: kinetic and equilibrium studies, Separ. Purif. Technol., 53, 97-110 and references cited therein.

Crossley P. 2001. Bauxite in 2001-getting a grip on supply, Industrial Minerals, 401, 27-41.

Das A.K., Saha S., Pal A. and Maji S.K. 2009. Surfactant-modified alumina: An efficient adsorbent for malachite green removal from water environment, J. Env. Sci. Health, Part A: Toxic/Hazardous Substances and Environmental Engineering, 44/9, 896-905.

Di Toro D.M., Mahony,J.D., Kirchgraber P.R., O’Byrne A.L., Pasqual, L.R. and Piccirilli D.C. 1986. Effects of nonreversibility, particle concentration, and ionic strength on heavy metal sorption, Environ. Sci. Technol., 20, 55-61.

Filippidis A., 2008. Treatment and recycling of municipal and industrial waste waters using Hellenic Natural Zeolite: A Review, AQUA, $3^{\text {rd }}$ Intern. Conf. Water Science and Technology with emphasis on water and climate, Athens, Greece, Proc., $5 \mathrm{p}$.

Filippidis A. 2010. Environmental, industrial and agricultural applications of Hellenic Natural Zeolite, Hellenic Journal of Geosciences, 45, 91-100.

Filippidis A. 2013. Industrial and municipal wastewater treatment by zeolitic tuff, Water Today, January, Volume-V (issue-X), 34-38.

Filippidis A., Apostolidis N., Paragios I. and Filippidis S. 2008. Purification of dye-work and urban wastewaters, production of odorless and cohesive zeo-sewage sludge, using Hellenic Natural Zeolite, $1^{\text {st }}$ Intern. Conf. Hazardous Waste Management, Chania, Greece, Proc., 8p.

Gong R., Jin Y., Chen F., Chen J. and Liu Z. 2006. Enhanced malachite green removal from aqueous solution by citric acid modified rice straw, J. Hazard. Mater. B, 137, 865-870.

Govindasamy V., Sahadevan R., Subramanian S. and Mahendradas D.K. 2009. Removal of malachite green from aqueous solutions by perlite, Int. J. Chem. Reactor Engin., 7, 1-20. 
Harben P.W. 2002. The Industrial Minerals HandyBook, Pensord, Blackwood, UK, 409 p.

Harben P.W. and Dickson E.M. 1983. Non-metallurgical grades-bauxite's crème de la crème, Industrial Minerals, 192, 25-43.

Jia Y.F., Xiao B. and Thomas K.M. 2002. Adsorption of metal ions on nitration surface functional groups in activated carbon, Langmuir, 18, 470-478.

Khattri S.D. and Singh M.K. 1999. Color removal from dye wastewater using sugar cane dust as an adsorbent, Ads. Sci. Tech., 17, 269-282.

Khattri S.D. and Singh M.K. 2000. Color removal from synthetic dye wastewater using a bioadsorbent, Water, Air, Soil Poll., 120, 283-294.

Kiskyras D. 1982. Characteristic features of the Greek bauxites in view of their origin, Proc. Academy Athens, 57, 82-95.

Krauskopf K.B.and Bird D.K. 1995. Introduction to geochemistry (3 ${ }^{\text {rd }}$ ed.), New York, McGrawHill, 647 pp.

Kumar K.V., Sivanesan, S. 2006. Pseudo second order kinetics and pseudo isotherms for malachite green onto activated carbon: Comparison of linear and non-linear regression methods, J. Hazard. Mater. B, 136, 721-726.

Kumar K. V. 2007. Optimum sorption isotherm by linear and non-linear methods for malachite green onto lemon peel, Dyes Pigments, 74, 595-597.

Kumar K.V. and Sivanesan S. 2007. Isotherms for malachite green onto rubber wood (Hevea brasiliensis) saw dust: Comparison of linear and non-linear methods, Dyes Pigments, 72, 124-129.

Limousin G., Gaudet J.-P., Charlet L., Szenknect S., Barthe`s V.and Krimissa M. 2007. Sorption isotherms: A review on physical bases, modelling and measurement, Appl. Geochem., 22, 249-275.

Mendez A., Fernandez F. and Gasco G. 2007. Removal of malachite green using carbon-based adsorbents, Desalination, 206, 147-153.

Mittal A. 2006. Adsorption kinetics of removal of a toxic dye, malachite green, from wastewater by using hen feathers, J. Hazard. Mater. B, 133, 196-202.

Nandi B. K., Goswami A., Das A. K., Mondal B. and Purkait M. K. 2008. Kinetic and Equilibrium Studies on the Adsorption of Crystal Violet Dye using Kaolin as an Adsorbent, Sep. Sci. Technol., 43, 1382-1403.

Onal Y., Akmil-Basar C. and Sarici-Ozdemir C. 2007. Investigation kinetics mechanisms of adsorption malachite green onto activated carbon, J. Hazard. Mater., 146, 194-203.

Prado A.G.S., Bolzon L.B., Pedroso C.P., Moura A.O.and Costa L.L. 2008. $\mathrm{Nb}_{2} \mathrm{O}_{5}$ as efficient and recyclable photocatalyst for indigo carmine degradation, Appl. Catal. B, 82, 219-224.

Preocanin T.and Kallay N. 2006. Point of zero charge and surface charge density of $\mathrm{TiO}_{2}$ in aqueous electrolyte solution as obtained by potentiometric mass titration, Croat. Chem. Acta, 79, 95-106.

Rouquerol F., Rouquerol J.and Sing K. 1999. Adsorption by powders and porous solids: Principles, methodology and applications. San Diego, Academic Press, 485 pp.

Singh R., Gupta J.R.P. and Prasad B.B. 1975. Adsorption of cationic dyes by activated alumina, Proc. Indian Natn. Sci. Acad., 41A, 163-169.

Srivastava S., Sinha R. and Roy D. 2004. Toxicological effects of malachite green, Aquatic Toxicology, 66, 319-329.

Tataris A. 1986. Bauxites-bauxitic clays (b2_3) of the "Intermediate" Limestone of the ParnassusGhiona zone. Origin of the bauxitic horizons material, IGME, Geol. Geophys. Res., Spec. Iss., 449-465.

Taylor L. 2003. Bauxite's strength in diversity, Industrial Minerals, 432, 62-67.

Voice T.C., Rice C.P.and Weber W.J. 1983. Effects of solids concentration on the sorptive partitioning of hydrophobic pollutants in aquatic systems, Environ. Sci. Technol., 17, 513-518.

Zhang J., Li Y., Zhang C. and Jing Y. 2008. Adsorption of malachite green from aqueous solution onto carbon prepared from Arundo donax root, J. Hazard. Mater., 150/3, 774-782. 